\title{
The Internationalisation of Financial Crises: Banking and Currency Crises 1883-2008
}

\author{
This version: January 2015
}

\begin{abstract}
Financial crises are high cost events which can transmit across international borders. Using data from 1883 to 2008, this paper develops a means of mapping changes in the degree of international synchronisation of banking and currency crises through a formal concordance index. This index specifically accounts for the typically low incidence and potential serial correlation of crisis data. The results show that banking crises were highly internationalised at the beginning of the 20th century, and became far less so in the strong regulatory environment prevailing after the Depression until the 1980s. A strong increase in the synchronicity of international banking crises is revealed during the late 20th and early 21st century. Currency crises began the century as more idiosyncratic, but have tended to become more synchronised over the 115 year sample.
\end{abstract}

Keywords: financial crises, currency crisis, banking crisis, synchronisation, concordance indices

JEL Classification: F31, F47, N20 


\section{Introduction}

Financial crises can have a huge impact on economies. Fortunately, they do not occur very often. Partly motivated by policy interest in mitigating their economic costs, there is a relatively large literature focussed on whether crises are becoming more linked across geographic borders. ${ }^{1}$ Important debates concern how to limit the probability, impact and spread of crises, particularly through various agenda on reforming global financial architecture. ${ }^{2}$

There is a substantial literature on various episodes of crisis from the late 19th century to the close of the 20th century. See for example Bordo and Schwartz (1996), Bordo et al. (2001), Eichengreen (2003), Isard (2005, Chapter 2), Eichengreen (2008), Kindleberger and Aliber (2011), and Reinhart and Rogoff (2011). The exact chronology of the period is not uniformly agreed, as rules for dating crises are notoriously imprecise. However, there is broad agreement about a number of periods.

Evidence suggests that the prevalence of financial crises has been increas-

\footnotetext{
${ }^{1}$ Some of the channels proposed include trade links (Glick and Rose, 1999); banking linkages (Van Rijckeghem and Weder, 2001); credit derivatives (Brunnermeier, 2009), the lack of common fundamental and institutional features, via contagion effects (Rose and Spiegel, 2010); and more recently via the real sector channel (Claessens, Tong, and Wei, 2012), leverage of banks and investors (Kalemli-Ozcan, Sorensen, and Yesiltas, 2012; Raddatz and Schmukler, 2012), and global banking networks (Hale, 2011; Claessens and van Horen, 2012; Cetorelli and Goldberg, 2012; Aiyar, 2012).

${ }^{2}$ See for example Eichengreen (2002) following the East Asian crisis and Brunnermeier et al. (2009) on the recent credit crunch and even Bagehot (1873). In recent literature, Barkbu, Eichengreen, and Mody (2011) propose global debt-restructuring for reducing future vulnerabilities. Dewatripont, et al. (2010) emphasize prudential bank regulation. Schinasi and Truman (2010) and Davies and Green (2010, Chapter 10) review the role of international financial institutions (the IMF, Bank for International Settlements, and the Financial Stability Board) in shaping the global financial architecture. Ostry et al. (2010) focus on the role of global capital controls in reducing financial fragilities. Beyond the economic literature there have been major policy agendas on regulatory reform driven by bodies such as the G20 - for example the G20 leaders Declaration on Strengthening the Financial System from the London meetings, released April 2, 2009.
} 
ing, particularly since World War II; Eichengreen and Bordo (2003), Kaminsky and Reinhart (1999), Glick and Hutchison (2001), Eichengreen (2008), and Reinhart and Rogoff (2011). However, measures of changes in the extent of internationalisation of crises are more scarce. It is of particular interest to understand whether more prevalent crises are internationally linked or are idiosyncratic and simply occur coincidentally.

The contribution of this paper is in developing a means of mapping changes in the degree of international synchronisation of financial crises from the late 19th century through to 2008 through a formal concordance index. To examine the history of crises, we use a sample of 21 countries' annual banking and currency crisis data for 1883 to 1998 drawn from Bordo et al. (2001), updated with the recent dataset of Laeven and Valencia $(2008,2013)$ to 2008. Post-2008 there are no crises indicated in any of sample countries in these datasets, thus we do not extend beyond this period as in our method this will not affect the results. In common with most crisis data, the sample consists of bivariate indices taking the value 1 in the presence of a crisis. Our concordance index uses this data to construct a measure ranging from 0 to 1 to characterise the extent of international interdependence in financial crises. A value of 1 indicates that all crises are simultaneous. The advantage of the concordance indices compared to the traditional correlation measure is the ability to investigate synchronisation among more than two crises, and to formally test for independence. These tests take into account the binary nature of the data, the relatively low incidence of crises, and potential serial correlation. When applied to the sample data they reveal that the occurrence of 5 (4) or more contemporaneous currency (banking) crises in the data is 
not likely to be coincidental.

The evolution of the concordance indices indicates that currency crises have not only become more prevalent but also more internationally synchronised over the twentieth century. Banking crises were highly internationalised at the beginning of the 20th century, but became far less so during the strong regulatory environment prevailing after the Depression until the 1980s. However, the incidence of banking crises has grown in the past 30 years, and the global financial crisis of 2007-2008 sees a jump in the synchronisation of these crises. Greater frequency of currency crises and lower frequency of banking crises are associated with capital controls by Glick and Hutchison (2001) and Kaminsky and Reinhart (1999). Coupling their results with the concordance indices reveals that more liberalized financial conditions are associated with a greater prevalence of banking crises at the end of the sample and increasing internationalisation of currency crises; this is consistent with the network analysis presented in IMF Global Financial Stability Report (2014), see particularly Box 3.1, and of Billio et al. (2012) and Giraitis et al. (2013). Although there are limited incidences of joint banking and currency crises (twin crises) in the data set, some analysis of their transmission is warranted in the light of their much higher cost for economies involved, see for example Stiglitz (2000), Bordo et al. (2001), Burnside, Eichenbaum, and Rebelo (2003), Hutchison and Noy (2005), Gupta, Mishra, and Sahay (2007) and Haugh, Ollivaud, and Turner (2009).

The paper proceeds as follows. Section ?? is methodological, presenting definitions of synchronisation, and bivariate and multivariate concordance indices and means of testing for independence between crises with these in- 
dices. After a description of the dataset in Section ??, Section ?? provides the results of applying our methodology to the sample data. Section ?? applies the multivariate concordance indices in an historical analysis of banking and currency crises in the 20th century. Section ?? concludes.

\section{Methodology}

\subsection{Synchronisation}

We consider $P$ countries and $Q$ markets. Let a financial crisis be represented by the binary variable $S_{i, t}$, where $i=1, \ldots, P Q, t=1, \ldots, n . \quad S_{i, t}$ takes the value one if a crisis occurs in the corresponding country and market in period $t$ and zero otherwise. The mean of the series $S_{i, t}, t=1, \ldots, n$, is denoted $\mu_{S_{i}}$. If two series are identical, that is $S_{x, t}=S_{y, t}$ for all $t$, the series are perfectly synchronised and have equal means and perfect positive correlation. When series exhibit strong synchronisation, the means of the two series and the correlation between them describe how synchronised the series are, omitting the uninteresting cases where the series are either continually in crisis, or continually not $\left(S_{x, t}=1\right.$ or $S_{y, t}=0$ for all $\left.t\right)$. For the remainder of this paper the means of the financial crises series and the number of observations are assumed known. ${ }^{3}$ Binary financial crises series typically have low incidence, are ordered in time, stochastically dependent and possibly serially correlated. A standard way of defining synchronisation is by

\footnotetext{
${ }^{3}$ The binary financial crisis dummy series are constructed from an underlying data generating process by clipping or hard limiting (Kedem, 1980) although there need not exist a clear link to the data generating process. We deviate from Harding and Pagan (2011) in this respect.
} 
means of correlation coefficients. However, there is no one-to-one relation between correlation coefficients and synchronisation. It is quite possible to observe series with equal means but different correlation coefficients, or sets of series with equal correlation coefficients but different means. In this case the synchronisation between the series will differ.

An alternative way to define synchronisation is from contingency tables which 'count' the number of times the variables $S_{x, t}$ and $S_{y, t}$ are in various combinations of states. ${ }^{4}$ Consider the following $(2 \times 2)$ contingency table.

Bivariate crises: $(2 \times 2)$ contingency table

\section{Crisis $S_{y} \quad$ No crisis $S_{y} \quad$ Row sums}

$\begin{array}{lccc}\text { Crisis } S_{x} & n_{11} & n_{12} & n_{1 .} \\ \text { No crisis } S_{x} & n_{21} & n_{22} & n_{2 .} . \\ \text { Column sums } & n_{.1} & n_{.2} & n\end{array}$

In the contingency table $n_{11}$ denotes the number of simultaneous crises, that is when $S_{x, t}=S_{y, t}=1, n_{12}$ the number of periods with a crisis of a type $x$ only, $n_{21}$ the number of periods with a single crisis of type $y$, and $n_{22}$ is the number of tranquil periods. The row and column sums are fixed, as well as the number of observations $n$. Therefore only one of the $n_{i j}$ can vary independently. Without loss of generality we take this to be $n_{11}$. As we will show next, the contingency table approach provides a useful means

\footnotetext{
${ }^{4}$ For an introduction to contingency tables see Agresti (2012, Chapter 2).
} 
of developing bivariate, and later multivariate, indices of the contemporary concordance between financial crises.

\subsection{Bivariate concordance indices}

Concordance indices can be simply constructed from a $2 \times 2$ contingency table like that shown above by 'counting' the number of times the variables $S_{x, t}$ and $S_{y, t}$ are in various combinations of states. In a bivariate setting the total observations in the sample $(n)$ consist of the number of simultaneous crises periods $\left(n_{11}\right)$, the number of periods with a single crisis $\left(n_{12}+n_{21}\right)$ and the number of tranquil periods $\left(n_{22}\right)$, or $n \equiv n_{11}+n_{12}+n_{21}+n_{22}$.

Harding and Pagan (2006) advocate measuring the degree of synchronisation in business cycles in terms of the fraction of time the cycles are in the same phase. Their concordance index has the form

$$
\hat{I}^{h p}=\frac{n_{11}+n_{22}}{n} .
$$

A typical feature of financial crises is their low incidence, or a large number of tranquil periods in the sample. It seems natural then to confine attention to the concordance of crises in turbulent periods and introduce the turbulentperiods concordance index

$$
\hat{I}=\frac{n_{11}}{n-n_{22}}
$$

where we assume that there is at least one crisis in the sample, i.e., $n_{22} \neq n$. Equation (??) gives the number of times in which the two markets are both in crisis as a proportion of the number of times there are any crises in the 
sample. The construction of the denominator removes the influence of the dominant proportion of non-crisis periods (all zeros) which would prevail if the Harding and Pagan indicator of Equation (??) was applied. ${ }^{5}$ Hence, the influence of the dominant non-crisis periods is removed.

Equation (??) can be expressed in terms of means and correlation coefficients as

$$
\hat{I}=\frac{\hat{\rho}_{s}\left(\hat{\mu}_{S_{x}}\left(1-\hat{\mu}_{S_{x}}\right)\right)^{1 / 2}\left(\hat{\mu}_{S_{y}}\left(1-\hat{\mu}_{S_{y}}\right)\right)^{1 / 2}+\hat{\mu}_{S_{x}} \hat{\mu}_{S_{y}}}{-\left(\hat{\rho}_{s}\left(\hat{\mu}_{S_{x}}\left(1-\hat{\mu}_{S_{x}}\right)\right)^{1 / 2}\left(\hat{\mu}_{S_{y}}\left(1-\hat{\mu}_{S_{y}}\right)\right)^{1 / 2}+\hat{\mu}_{S_{x}} \hat{\mu}_{S_{y}}\right)+\hat{\mu}_{S_{x}}+\hat{\mu}_{S_{y}}},
$$

where $\hat{\rho}_{s}$ represents the sample correlation coefficient between the two crisis indices $S_{x, t}$ and $S_{y, t}$. This function is plotted in Figure 1 for the example of equivalent means in the two series. Figure 1 shows that high concordance is achieved when correlation is high, $\hat{\rho}_{s}=1$ or means are high $\hat{\mu}_{x}=\hat{\mu}_{y}=1$, or a combination of these two characteristics. As either $\hat{\rho}_{s}$ or $\hat{\mu}_{x}=\hat{\mu}_{y}$ approach one, the value of the concordance index increases. This makes sense because the possibility of overlap increases as the number of crisis observations in the sample increases, even in the extreme case of independence of crises (a topic to which we return below).

\subsection{Multivariate concordance indices}

Consider the more interesting case of concordance in the context of multiple financial crises across countries for any particular market. Clearly synchronisation cannot be expressed in correlation coefficients any more, unless we

\footnotetext{
${ }^{5}$ The bivariate signal extraction measure used in Glick and Hutchison (2001) also makes the modification of removing non-crisis periods from the denominator.
} 
consider all bivariate combinations appropriate. However the contingency table framework can be extended from bivariate to multivariate.

Any instances of concordance across the indices for a particular market may be of interest, focussing attention on the joint occurrence of two or more crises. Denoting $Z$ as the minimum number of crises to occur concurrently, we can work out the frequency of observing $Z$ crises in $n$ periods as $f_{Z}=n$ multichoose $Z=\frac{n !}{(n-Z) ! Z !}$. So the frequency of observing $Z$ or more crises in $n$ periods must be the sum of $f_{z}$ for all $z \geq Z$.

The total number of periods $n$ is divided into periods involving multiple crises, denoted $n_{z}$, which can be further separated into $n_{z \geq Z}$ where there are $Z$ or more crises contemporaneously and $n_{1 \leq z<Z}$, where there are less than $Z$ crises but at least one, and the number of periods involving no crises in any country, denoted $n_{z=0}$, so that $n \equiv n_{z \geq Z}+n_{1 \leq z<Z}+n_{z=0}$. Then the multivariate version of our concordance index is expressed as

$$
\hat{I}^{M}=\frac{n_{z \geq Z}}{n-n_{z=0}} .
$$

Movements in this index are easily interpreted. An increase in the value of the index simply indicates that further episodes of concurrent financial crises have occurred (both the numerator and denominator have increased, recalling that we have omitted the uninteresting case of perfect synchronisation to ensure that the index is not equal to one). In the case of no change in the index, there have been no periods of turmoil and neither numerator or denominator of the index change. Declines in the index indicate the occurrence of isolated crises so that the denominator increases without an accompanying change 
in the numerator. This trade-off is illustrated in Figure 2 which shows the multivariate version of the index for $Z=2$, with equal means for all series.

Before turning to the applications of the concordance indices and the historical analysis, we consider tests for independence between series based on the concordance indices.

\subsection{Testing synchronisation}

To test whether synchronisation is not coincidental involves testing for independence. In the case of bivariate combinations of crises this could be done by a correlation coefficient test, tests in the contingency table framework of Section 3.1, or by simulation. And each of these has analogues for the multivariate case. One complication is the potential serial correlation of the binary crises data. In other applications with constructed binary indices from observed data generating processes, a test for correlation takes the possibility of serial correlation and heteroskedasticity into account as in Harding and Pagan (2006). Here we apply tests based on the contingency table framework and simulation methods. We explicitly make use of the low incidence of financial crises and the resulting discrete distributions which enable the design of exact tests. We pretest each binary crisis series for serial correlation with a Fisher exact test using the null of independence against a higher-order Markov chain. ${ }^{6}$ A rejection of the null indicates serial correlation, although does not uniquely establish its Markov chain order.

\footnotetext{
${ }^{6}$ For a description of Fisher's exact test for $2 \times 2$ tables see Agresti (2012, Section 3.5) For statistical inference with Markov chains see e.g. Anderson and Goodman (1957).
} 
At least one of the countries exhibits serial correlation in each of the banking and currency crisis series. For this reason we test bivariate and multivariate synchronisation using simulation techniques. We simulate the series $\tilde{S}_{x}$ to have the same properties as $S_{x}$. Under the null hypothesis that the observed number of crises are randomly drawn from a uniform $(0,1)$ distribution, the number of observed crises in the data set gives the exact number of draws to simulate, that is in each case the $\mu_{x}=\tilde{\mu}_{x}$ where the latter term is the mean of the simulated series. In cases where $S_{x}$ rejects the null of independence, i.e., is serially correlated, the simulated data uses the observed runs of contiguous crises in the original data in simulating to retain the serial correlation properties in the simulated data. We use 10,000 replications to generate the critical values. Converting these critical values for the totals into critical values for the bivariate and multivariate concordance indices is straightforward from Equations (??) and (??).

\section{Data}

To investigate the measurement of synchronisation of crises we use the long run annual data set of Bordo et al. (2001) for currency and banking crises for 21 countries over the period 1883 to 1998, and update this to 2008 with the crisis data provided in Laeven and Valencia (2008, 2013). In Bordo et al. currency crises occur in association with either a forced change in parity, a realignment or as indicated by an exchange market pressure index exceeding a threshold value. ${ }^{7}$ In Laeven and Valencia $(2008,2013)$ currency

\footnotetext{
${ }^{7}$ The exchange market pressure index is constructed as a weighted sum of exchange rates, interest rate differentials and changes in reserves as per Eichengreen, Rose and
} 
crises are indicated by a currency depreciation of at least $30 \%$, where this is at least $10 \%$ greater than the rate of depreciation in the previous year. This did not occur for any of the currencies in the sample in 2008. Banking crises in Bordo et al. are dated as periods of continuous financial distress leading to substantial erosion of banking capital, as per Caprio and Klingebiel (1996). Laeven and Valencia $(2008,2013)$ use a combination of qualitative and quantitative indicators, see their papers for details.

The data set takes the form of annual binary indices, taking a 1 in years when a crisis occurs, and a 0 otherwise. The countries included are Argentina, Australia, Belgium, Brazil, Canada, Chile, Denmark, Finland, France, Germany, Greece, Italy, Japan, the Netherlands, Norway, Portugal, Spain, Sweden, Switzerland, the UK and the US. Table ?? shows the occurrences of the crises in the dataset. ${ }^{8}$ While it would be interesting to include Asian economies in this chronology the data simply do not exist. The Table clearly shows the greater prevalence of currency crises than banking crises; only in the US, Italy and Belgium have there been more banking crises than currency crises for a particular country. The Table also indicates the incidence of joint occurrence of contemporaneous banking and currency crises in a single country, labelled twin crises. Compared with the occurrence of single crisis types, twin crises are uncommon, a feature also apparent in the data sets of Kaminsky and Reinhart (1999), Glick and Hutchison (2001), and Laeven and Valencia (2013).

${ }^{8}$ Obviously, alternative crisis dating rules would result in somewhat different crises chronologies; see Lestano and Jacobs (2007) for a discussion of the sensitivity of currency crises dating methods.
} 
Figures 3 and 4 give the time distribution of each of the currency and banking crises. What is immediately apparent is the relative infrequency of these events; there are many more non-crisis years than crisis years. Particular years stand out. In 1907 a banking crisis occurred in seven of the 21 countries in the sample - see Goodhart and Delargy (1998). Both banking and currency crises were widespread in 1931 associated with the Great Depression, with eight countries experiencing both banking and currency crises (twin crises); a further five countries experienced a banking crisis alone, and a further six countries a currency crisis alone.

The next major period of disruption in the sample is the currency crises associated with the breakdown of Bretton Woods in 1971 when 12 countries observed currency crises (but not banking crises). The third major set of currency crises in the dataset occurs in the 1992 ERM crisis, when the UK and Italy exited the system, and seven of the European countries report a crisis observation (Denmark, France, Italy, the Netherlands, Spain, Sweden and the UK). Banking crises in this data set do not meet with pre-World War II levels again. The 1997-1998 period of the East Asian currency crisis does not stand out in the results because the dataset does not include data on Asian economies, and although there was extensive contagion and spillovers associated with the Asian crisis within Asia, the evidence for impact on the rest of the world is limited; see for example Dungey and Martin (2007), Dungey, Fry and Martin (2006).

Finally, in 2008 there is a cluster of banking crises across 10 of the countries in the sample. These crises are associated with the events in the world's developed markets at this time resulting from the credit crunch associated 
with the mortgage backed securities market in the US and the fall of Lehman Bros in the US, the nationalisation and failure of significant financial institutions in the UK and Europe, including for example Northern Rock, ABN AMRO, UBS and Royal Bank of Scotland. ${ }^{9}$ These clusters of failing financial institutions have prompted significant response from regulatory bodies, and international organisation such as the BIS and IMF. Reviews of this period can be found in Shin (2009), IMF Global Financial Stability Report (2009), and Gorton and Metrick (2012).

\section{Test outcomes}

Table ?? shows the results of pretesting independence against a first order Markov process on the transition matrices as described in the previous section for currency and banking crises in each of the 21 countries. As is quickly observed, almost all series display independence.

\subsection{Bivariate concordance}

Table ?? shows bivariate turbulent-period concordance indices for currency crises with corresponding $95 \%$ critical values in the upper and lower triangles of the table, respectively. The critical values are obtained by simulation as described in the previous section. The country pairs for which currency crises reject the null of independence predominantly involve crises where two European countries are involved. For example, the results for Finland show

\footnotetext{
${ }^{9}$ For a dissenting view that finds that these crises are not associated with global events see the evidence in Shehzad and De Haan (2013).
} 
that nine of the rejections of independence involve other European countries (Belgium, Greece, Netherlands, Norway, Poland, Spain, Sweden and the UK) and three non-European pairs with Argentina, Australia and Canada. The Netherlands, Norway and Poland show similar patterns. Argentina is also frequently one of the pair considered in bivariate tests which reject independence, including with all other Latin American countries. A number of authors have proposed mechanisms which may result in regional clustering of financial crises. These include trade and financial linkages, such as in Van Rijckeghem and Weder (2001). Linkages through banking relationships have been shown to be strongly associated with contagion and the transmission of crises in a number of cases, including empirical evidence in Van Rijckeghem and Weder (2003), and a theoretical model based on cross-market rebalancing in Kodres and Pritsker (2002). The role of global banks in transmitting the recent crisis is addressed in Cetorelli and Goldberg (2011). Their results are also consistent with the hypothesis that the degree of economic development can influence regional clusterings, supported in Kaminsky and Reinhart (2008) who particularly point to the function of developed financial markets in transmitting crises between emerging market regions.

Table ?? lists bivariate turbulent period concordance indices and corresponding $95 \%$ critical values derived from simulation for banking crises. Serial correlation has been taken into account for France, Norway and the US. There are a substantial number of incidences of rejections of independence between the bivariate banking crises. The greatest number of rejections as part of a pair occur for the US, likely reflecting its status as a world financial centre during much of the sample period. Italy, Belgium and Poland have 
the next greatest number of rejections, rejecting independence in bivariate crisis observations with most European countries as well as the US - this reflects the European focus of these countries and their close involvement with their neighbours, as illustrated for the recent period in Box 3.1 of IMF Global Financial Stability Report (2014). Similarly, potentially reflecting the strong cross-border banking relationships, the UK only rejects independence in bivariate pairs of crisis with the US. Despite the differences between the banking system in Japan and other countries, see Allen et al. (2010) and Sylla and Wright (2004), there are no incidences in which independence is rejected for bivariate relationships with Japan.

Given the relationships revealed by the bivariate indices we now consider the testing of multivariate concordance.

\subsection{Multivariate concordance}

Table ?? reports the multivariate concordance indices for the group of crises across countries over the entire sample. Each row reports the concordance index for the stated number of common crises shown in the first column. So the first row reports the concordance index for at least two concurrent currency crises across the 21 economies sampled. A total of 39 time periods are identified which fulfill that criteria, giving a turbulent periods index of 0.57 .

The final column of Table ?? reports the $95 \%$ critical value for the concordance indices in each case expressed as the maximum number of times that one would observe that many crises and be able to reject the null of in- 
dependence at the $5 \%$ level. That is for the row of at least two simultaneous currency crises, one can observe up to 18 occurrences of two simultaneous crises without having to reject independence. In the sample there are 39 occurrences of at least two simultaneous currency crises, clearly rejecting independence. In the case of banking crises, the row labelled at least two crises contains 26 observations with a turbulent periods index value of 0.59 for the sample. One can observe up to seven cases of two simultaneous crises whilst being consistent with independence, which is clearly rejected by the 26 cases observed in the dataset. The results in Table ?? show that the sample rejects independence between simultaneous crises in all instances. The Table shows that a single occurrence of five simultaneous currency crises (four simultaneous banking crises) is sufficient to reject independence in the data.

Policy makers are correct to be concerned about the occurrence of a crisis. However, knowing which crises are going to spread is as yet unresolved. There is a large literature identifying the existence of channels of contagion and spillover from one crisis country to another; see for example Dungey and Martin (2007), Dungey, Milunovich and Thorp (2010), Bekaert et al. (2011). However, isolating the characteristics of what makes a particular crisis spread, what makes other markets vulnerable to spread from other crises and predicting crises remain important issues, and are the focus of work on indicators of financial fragility such as associated with Goldstein, Kaminsky and Reinhart (2000). Unfortunately this literature has not been particularly successful to date, with the relatively poor performance of these indicators documented in Berg and Pattillo (1999) and Berg, Borensztein, and Pattillo (2004). Further, the cross-section analysis of Rose and Spiegel 
(2010) suggests little commonality in macroeconomic and institutional settings across countries affected by the 2007-2008 global financial crisis, and Agarwal et al (2013) do not find strong indicators of future instability via external sector imbalances —although Lane and Milesi-Ferretti (2012) find some commonalities in the pre-crisis macroeconomic conditions for economies severely affected by the crisis they are not able to establish a mechanism for these relationships. The problem lies both with the heterogeneity of the crises; it seems no two crises are ever the same, and with the availability of data. There is a significant data gap problem in identifying cross-border bilateral and timely datasets for use in detecting and assessing crises. The extent of this problem is described in the G-20 Financial Stability Board work on data gaps, IMF-FSB (2009), and the coverage of data issues with respect to systemic risk in Bisias et al. (2012). However, it is well-known that crisis situations will tend to exacerbate other weaknesses in the economy and financial systems, see for example the analysis in Reinhart and Rogoff (2009), IMF Global Financial Stability Reports (2009, 2014) and references therein and for a direct example of how interlinkages between financial and non-financial sectors affect systemic risk see Dungey, Luciani and Veredas (2013).

\subsection{Twin crises}

Before proceeding to the analysis of the internationalisation of banking and currency crises over time we first examine the evidence on twin crises; that is where a banking and currency crisis occur simultaneously. Twin crises 
are well known to be more costly than individual crises. Bordo et al. (2001) calculate the output loss of twin crises as twice as costly as currency crises and four times more costly than banking crises, see also Kaminsky and Reinhart (1999), and Stiglitz (2000). The lack of occurrences of twin crises in the dataset prohibits the construction of an informative concordance index. ${ }^{10}$

Table ?? illustrates the joint occurrence of contemporaneous currency and banking crises. The columns give the number of occurrences of either no, one or multiple contemporaneous banking crises, while the rows give the same information for currency crises. As already seen the most populous combination is a non-crisis period (the top left cell), with 46 of the 126 sample observations. The presence of both multiple banking and currency crises only numbers 13, of which twin crises (restricted to occur in the same country) are a subsample. It is worth noting that the number of periods with no currency crises but one or more banking crises is very small at seven (of a total of 39 banking crises in the sample), while the number of periods with no banking crises but one or more currency crises is 36, or 52 percent of the 69 periods containing currency crises. It seems that the occurrence of banking crises in isolation from currency crises somewhere in the world is much less likely than the occurrence of currency crises in isolation from banking crises somewhere in the world. In this respect the events of 2007-2008 have been

\footnotetext{
${ }^{10}$ Both Kaminsky and Reinhart (1999) and Glick and Hutchison (2001) avoid the problem of low incidence of contemporaneous crises by defining a window in which crises may occur and still be considered twin. We have constructed a similar index of twin crises to Glick and Hutchison, which increases the number of incidences in our sample from 21 (of which 3 are post World War II) to almost 50 (with 13 post World War II), however the method induces serial correlation into the index data which further complicates statistical analysis. Neither Kaminsky and Reinhart (1999) nor Glick and Hutchison (2001) deal with this complication.
} 
unusual in being dominated by banking crises. This outcome suggests an hypothesis for future research as to whether the size of the banking system in the originating country, the US, and/or the monetary union in the EU, were contributing factors.

\section{$5 \quad$ Historical analysis}

Chronologically the first period runs from the late 19th century to the beginning of World War I associated with the period of the gold standard. Two major crises from this period were the Barings scandal resulting from overinvestment in Latin America, and the banking panic in the US and other countries in 1907 and 1908. This period is covered in some detail in the Appendix to Bordo and Eichengreen (1999).

The interwar period can be divided into two. The first covers the decade from 1919 to 1929, characterised by the attempts to return the international financial system to the gold standard and the consequent strains placed on economies in aligning their internal and external positions, as discussed by Isard (2005). The period from 1929 to the advent of World War II includes the Depression and the greatest concentration of both banking and currency crises in developed nations as the gold standard was broken, resulting in what Isard (2005) calls an 'uncoordinated hybrid system'. The period of the second World War was one of tight controls and produces no crisis data.

Post World War II, the next 25 years are characterised by the exchange rate arrangements of Bretton-Woods. During the Bretton-Woods era currency crises were prevalent, and as Bordo and Schwartz (1996) discuss, of- 
ten traumatic due to the need to align the internal economy with previously agreed rates and political difficulties in making changes to the exchange rates. Following the breakdown of Bretton-Woods in 1971, an increasing number of countries adopt floating exchange rates. The 1990s in particular seems to have been characterised by plentiful financial crises, including the East Asian crisis, comprising both currency and banking crises across a variety of countries. The high incidence of crises in these years is noted by both Crockett (2004) and Haldane and Kruger (2004).

Finally, 2007-2008 represents the period of greatest financial turmoil since the crises associated with the Great Depression. The source of the crisis is widely regarded to be the collapse of the securitised market for sub-prime mortgages in the US, which in itself was riding the back of a housing price bubble likely exacerbated by relatively loose monetary policy. Financial innovation and a tendency to self-regulation in new financial products contributed to the creation of a set interlinkages based on credit derivatives and regulatory arbitrage which seriously threatened the most developed markets and their economies. Descriptions of this crisis can be found in Brunnermeier et al. (2009), Rose and Spiegel (2010), Financial Crisis Inquiry Commission (2011), and Eichengreen (2011, Chapter 5).

Figure 5 shows recursive calculations of the multivariate concordance indices for banking and currency crises using the initial 20 observations of the dataset as the starting point and increasing the sample size by one observation at the time. Increases in the concordance index indicate an increase in international financial turmoil. A stable concordance index is associated with a period of tranquility. A decrease in the concordance index is equally 
informative, as it signals an increase in isolated financial turmoil, that is turmoil confined to single (or small groups of countries if $Z>2$ ). Figure 5 shows the recursive concordance index for the case of two or more simultaneous crises, so that a decline in this index is associated with the occurrence of isolated single crises. Similar indices can be constructed for higher numbers of simultaneous crises, but the results are consistent with the analysis presented here.

We observe a constant value of the currency concordance index from 1908 to 1920, indicating periods of tranquility during the gold standard for currencies. As discussed above, the 1920s is characterised by periods of currency crises. There are instances of both increased international turmoil (increases in the index) and of isolated turmoil (decreases in the index). The most pronounced feature of the figure is the large increase in the currency crisis concordance index in the early 1930s, associated with several years of contemporaneous crises, 14 in 1931 and 6 in 1932 as shown in Figure 3. This is followed by a few isolated crises in the mid 1930s and then the stability associated with controls during World War II. The Bretton-Woods era divides clearly into two components, the general movement in the index to the mid 1960s is downwards, reflecting isolated currency crises. From 1963 onwards the index begins to increase, indicating increasing internationalisation of crises, reflecting the building pressure towards the end of Bretton-Woods in 1971. The index climbs in the 1970s before a brief hiatus after the second oil price shock. From 1992 and the ERM crisis, however, the general impression is again of increasing internationalisation of currency crises.

The banking concordance index begins at a higher level than the currency 
crisis index, referring to the greater degree of disruption in the late 19th century in banking than in currency markets. For the period up to World War II the pattern is not dissimilar to that of the currency crises. The index falls in the 1920s reflecting isolated turmoil, and then rises in 1931 and 1932 reflecting the Depression period. A very long stable period in the banking crisis concordance index prevails during the post World War II period until 1963, when there is a banking crisis in Brazil. Stability again ensues until 1976. The scattering of isolated banking crises shown in Figure 4 then results in further falls in the index. The index then decreases up to 1986, followed by a period of increase to 1991 associated with increased international turmoil. Thereafter the index is relatively stable until the recent period where it has recently kicked up again to levels last seen in the 1991. The lack of new banking crises in our dataset post-2008 means that the index will remain at the final level over the subsequent period. Beck, Demirgüç-Kunt and Levine (2006) hypothesise that increased concentration in the banking sector is associated with fewer crises on data for 1980-1997. As discussed in OECD (2010) while banking concentration may appear to be associated with Australia's resilience to the 2008 crisis period, this contrasts with experience of other countries with concentrated banking systems, such as Ireland and the Netherlands, which were severely affected by the crisis.

The tests of multivariate synchronisation provided in the previous section mean that it is possible to identify particular points in time which contribute statistically significant information to the analysis. These are when there are 5 (4) or more contemporaneous currency (banking) crises. In terms of currency crises this occurs in 1921, 1931, 1932, 1949, 1971, 1976, and 1992. 
Each of these periods are well known stress points in historical analysis. In banking crises 4 or more crises are observed in 1907, 1921, 1923, 1931, 1932 and then-taking into account that our dataset does not cover the Asian economies affected by the Asia crisis in 1997-98 - a very long hiatus in internationally synchronised banking crises until 2008 .

An interesting aspect of Figure 5 is that the historical pattern differs across the two indices. ${ }^{11}$ In general there have been more periods of international financial turmoil in currency crises, leading to an increase in the index over the 20th century, while banking crises have tended to be more internationally linked at the beginning of the century than the end. Banking crises have tended to have relatively more independent occurrences following the Great Depression until the last decade of the 20th century. There is a disturbing uptick in the internationalisation of banking crises in the late 20th and early 21st centuries.

Finally, increasing incidence of currency crises has been associated with periods of war by Bordo and Schwartz (1996), Bordo and Eichengreen (1999), and Eichengreen (2008). Considering the Wars that occur in the 20th century as the Boer War (1899-1902), World War I (1914-1918), World War II (1939-1945), the Korean War (1950-1953), the Vietnam War (1962-1973) and the Gulf Wars $(1991,2003-2008)$ we see that the two wars where the hypothesis of increasing currency crisis sychronisation is evidently upheld here are the Korean and Vietnam Wars. In the 1930s there was an increase in currency crisis synchronisation, and to the (large) extent that the poor inter-

\footnotetext{
${ }^{11}$ The values of the indices are coincidentally similar at the end of the period, but little can be read into this given the different numbers of crises experienced.
} 
war economic conditions contributed to World War II, this also supports the association between war and currency crises.

\section{Conclusion}

This paper developed a multivariate turmoil-periods concordance index for financial crises in order to provide a measure of the degree of internationalisation of banking and currency crises. The index is readily interpretable over time and accounts for the typical properties of crisis data, i.e. binary, low incidence, potentially serially correlated crisis events. The index can be used to assess the independence of observed events, using simply constructed critical values. Moves in the multivariate turmoil-periods concordance index indicate the changing pattern of financial turmoil in world financial markets for the period 1883-2008. The index is stable during periods without financial crises, declines in the presence of independent crises and increases when internationally linked financial crises occur.

The degree of international financial turmoil in currency crises was shown to have broadly risen over the 20th century, associated with a rise in the currency crisis turbulent-periods concordance index. Banking crises were highly internationalised at the beginning of the sample, and following the crises of 1931 experienced a relatively crisis free period, associated with the strict regulatory structures of the post Depression era (through War controls, the Bretton Woods system). The degree of international financial turmoil in banking crises fell until late in the 20th century, shown as a fall in the banking crisis turbulent-periods concordance index. However, in the late 20th century 
and first decade of the 21st century, the banking crisis concordance index has risen again. This reflects the internationalisation of recent banking crisis episodes, particularly the global financial crisis of 2007-2008. 


\section{Acknowledgements}

A previous version of the paper circulated under the title 'Synchronisation of financial crises'. Drafts of this paper were written during visits of the first two authors to the Cambridge Endowment for Research in Finance (CERF) and Queens' College, University of Cambridge and CenTER, Tilburg University. We thank these institutions, and particularly John Eatwell and Daan van Soest, for their hospitality. Dungey acknowledges funding from ARC Grant DP0343418, Jacobs acknowledges support from the Research School SOM, University of Groningen. Lestano acknowledges support of the Atma Jaya Catholic University and thanks the University of Groningen. The present version of the paper has benefited from suggestions of an anonymous referee, Dirk Baur, Jerry Dwyer, Don Harding, Patrick Honohan, Brian Lucey, Adrian Pagan, Elmer Sterken and Mervyn Silvapulle, and comments following several seminar and conference presentations. 


\section{References}

Aiyar, S. (2012). From Financial Crisis to Great Recession: The Role of Globalized Banks. American Economic Review, 102(3), 225-230.

Agresti, A. (2012). Categorical Data Analysis. Hoboken, New Jersey: John Wiley \& Sons.

Allen, F., Capie, F., Fohlin, C., Miyajima, H., Sylla, R., Wood, G., \& Yafeh, Y. (2010). How Important Historically Were Financial Systems for Growth in the U.K., U.S., Germany, and Japan? Prepared for the World Bank Project on Financial Structure.

Anderson, T. W., \& Goodman, L. A. (1957). Statistical Inference about Markov Chains. The Annals of Mathematical Statistics, 28(1), 89-110.

Agarwal, M., Walsh, S., Wang, J., Whalley, J.\& Yan, C. (2013). Expected Worsening or Improving Financial Instability and the 2008 Financial Crisis. North American Journal of Economics and Finance, 26, 92-105.

Bagehot, W. (1962) [1873]. Lombard Street. A Description of the Money Market. Homewood, Illinois: Richard D. Irwin.

Barkbu, B., Eichengreen, B., \& Mody, A. (2011). International Financial Crises and the Multilateral Response: What the Historical Record Shows. NBER Working Paper No. 17361. Cambridge, Massachusetts: National Bureau of Economic Research.

Beck, T., Demirgüç-Kunt, A., \& Levine, R. (2006). Bank Concentration, Competition, and Crises: First Results. Journal of Banking ES Finance, 30(5), 1581-1603. 
Bekaert, G., Ehrmann, M., Fratscher, M., \& Mehl, A. J. (2011). Global Crises and Equity Market Contagion. NBER Working Paper No. 17121. Cambridge, Massachusetts: National Bureau of Economic Research.

Berg, A., \& Patillo, C. (1999). Are Currency Crises Predictable? A Test. IMF Staff Papers No. 46/2. Washington, D.C.: International Monetary Fund.

Berg, A., Borensztein, E., \& Pattillo, C. (2004). Assessing Early Warning Systems: How Have They Worked in Practice? IMF Working Papers No. 04/52 Washington, D.C.: International Monetary Fund.

Billio, M, Getmansky, M., Lo, A.W., \& Pelizzoni, L. (2012). Econometric Measures of Connectedness and Systemic Risk in the Finance and Insurance Sector. Journal of Financial Economics 104(3), 536-559.

Bisias, D., Flood, M., Lo, A. W., \& Valavanis, S. (2012). A Survey of Systemic Risk Analytics. Working Paper \#0001, Office of Financial Research, U.S. Department of the Treasury.

Bordo, M. D., \& Eichengreen, B. (1999). Is Our Current International Economic Environment Unusually Crisis Prone? In D. Gruen, \& Gower, L. (Eds.), Reserve Bank of Australia 1999 Conference, Capital Flows and the International Financial System. Sydney: Reserve Bank of Australia.

Bordo, M. D., Eichengreen, B., Klingebiel, D., Martinez-Peria, M.S., \& Rose, A. K. (2001). Is the Crisis Problem Growing More Severe? Economic Policy, 16(32), 53-82. 
Bordo, M. D., \& Schwartz, A. J. (1996). Why Clashes between Internal and External Stability Goals end in Currency Crises, 1797-1994. Open Economies Review, 7(1), 437-468.

Brunnermeier, M. K. (2009). Deciphering the Liquidity and Credit Crunch: 2007-2008. Journal of Economic Perspectives, 23(1), 77-100.

Brunnermeier, M. K., Crockett, A., Goodhart, C., Persaud, A. D., \& Shin, H. (2009). The Fundamental Principles of Financial Regulation: Geneva Reports on the World Economy 11. London: International Center for Monetary and Banking Studies and Centre for Economic Policy Research.

Burnside, C., Eichenbaum, M., \& Rebelo, S. (2003). On the Fiscal Implications of Twin Crises. In M. P. Dooley \& J. A. Frankel (Eds.), Managing Currency Crises in Emerging Markets. Chicago and London: The University of Chicago Press.

Caprio, G. Jr., \& Klingebiel, D. (1996). Bank Insolvencies: Cross-country Experience. Policy Research Working Paper No. 1620. Washington, D.C.: World Bank.

Cetorelli, N., \& Goldberg, L. S. (2012). Follow the Money: Quantifying Domestic Effects of Foreign Bank Shocks in the Great Recession. American Economic Review, 102(3), 213-218.

Claessens, S., Tong, H., \& Wei, S.-J. (2012). From the Financial Crisis to the Real Economy: Using Firm-level Data to Identify Transmission Channels. Journal of International Economics, 88(2), 365-387. 
Claessens, S., \& van Horen, N. (2012). Foreign Banks: Trends, Impact and Financial Stability. IMF Working Paper No. 12/10. Washington, D.C.: International Monetary Fund.

Crockett, A. (2004). Progress Towards Greater International Financial Stability. In D. Vines \& C. L. Gilbert (Eds.), The IMF and its Critics: Reform of Global Financial Architecture. Cambridge, United Kingdom: Cambridge University Press.

Davies, H., \& Green, D. (2010). Banking on the Future: the Fall and Rise of Central Banking. Princeton, New Jersey: Princeton University Press.

Dewatripont, M., Rochet, J.-C., Tirole, J., \& Tribe, K. (2010). Balancing the Banks: Global Lessons from the Financial Crisis. Princeton, New Jersey: Princeton University Press.

Dungey, M., Fry, R., \& Martin, V. L. (2006). Correlation, Contagion, and Asian Evidence. Asian Economic Papers 5(2), 32-72.

Dungey, M., Luciani, M., \& D. Veredas (2013). Googling SIFIs. Systemic Risk: Liquidity Risk, Governance and Financial Stability, SSRN abstract $=2166504$.

Dungey, M. \& Martin, V. L. (2007). Unravelling Financial Market Linkages during Crises. Journal of Applied Econometrics, 22(1), 89-119.

Dungey, M, and Milunovich, G. \& Thorp, S. (2010). Unobservable Shocks as Carriers of Contagion, Journal of Banking \& Finance, 34(5), 1008-1021.

Eichengreen, B. (2002). Financial Crises and What to Do about Them. Oxford: Oxford University Press. 
Eichengreen, B. (2003). Capital Flows and Crises. Cambridge, Massachusetts: The MIT Press.

Eichengreen, B. (2008). Globalizing Capital: A History of the International Monetary System. Princeton, New Jersey: Princeton University Press.

Eichengreen, B. (2011). Exorbitant Privilege: The Rise and Fall of the Dollar. Oxford: Oxford University Press.

Eichengreen, B., \& Bordo, M. D. (2003). Crises Now and Then: What Lessons from the Last Era of Financial Globalization? In P. Mizen (Ed.), Monetary History, Exchange Rates and Financial Markets: Essays in Honour of Charles Goodhart. Cheltenham, United Kingdom: Edward Elgar.

Eichengreen, B., Rose, A. K., \& Wyplosz, C. (1995). Exchange Market Mayhem: The Antecedents and Aftermath of Speculative Attacks. Economic Policy, 10(21), 249-312.

Eichengreen, B., Rose, A. K., \& Wyplosz, C. (1996). Contagious Currency Crises: First Tests. Scandinavian Journal of Economics, 98(4), 463-484.

Financial Crisis Inquiry Commission (2011). The Financial Crisis Inquiry Report: Final Report of the National Commission on the Causes of the Financial and Economic Crisis in the United States. Washington, D.C.: U.S. Government Printing Office.

Financial Stability Board and International Monetary Fund (2009). The Financial Crisis and Information Gaps. Basel, Switzerland: Financial Stability Board. 
Giraitis, L., Kapetanios, G., Wetherilt, A., \& Zikes, F. (2013). Estimating the Dynamics and Persistence of Financial Networks, with an Application to the Sterling Money Market. Presented at the 2013 Conference on Crosssectional Dependence in Panel Data at Cambridge University.

Glick, R., \& Hutchison, M. M. (2001). Banking and Currency Crises: How Common Are Twins? In R. Glick, R. Moreno, \& M. M. Spiegel (Eds.), Financial Crises in Emerging Markets. Cambridge, United Kingdom: Cambridge University Press.

Glick, R., \& Rose, A. K. (1999). Contagion and Trade: Why Are Currency Crises Regional? Journal of International Money and Finance, 18(14), 603-617.

Goldstein, M., Kaminsky, G. L., \& Reinhart, C. M. (2000). Assessing Financial Vulnerability: An Early Warning System for Emerging Markets. Washington, D.C.: Institute for International Economics.

Goodhart, C., \& Delargy, P. J. R. (1998). Financial crises: plus ça change, plus c'est la même chose. International Finance, 1(2), 261-287.

Gorton, G.B., \& Metrick, A. (2012). Getting Up to Speed on the Financial Crisis: A One-Weekend-Reader's Guide. Journal of Economic Literature, 50(1), 128-150.

Gupta, P., Mishra, D., \& Sahay, R. (2007). Behavior of Output During Currency Crises. Journal of International Economics, 72(2), 428-450.

Haldane, A. G., \& Kruger, M. (2004). The Resolution of International Financial Crises: An Alternative Framework. In D. Vines \& C. L. Gilbert 
(Eds.), The IMF and its Critics: Reform of Global Financial Architecture. Cambridge, United Kingdom: Cambridge University Press.

Hale, G. B. (2011). Bank Relationships, Business Cycles, and Financial Crises. NBER Working Paper No. 17356. Cambridge, Massachusetts: National Bureau of Economic Research.

Harding, D., \& Pagan, A.R. (2006). Synchronisation of Cycles. Journal of Econometrics, 132(1), 59-79.

Harding, D., \& Pagan, A.R. (2011). An Econometric Analysis of Some Models for Constructed Binary Time Series. Journal of Business and Economic Statistics, 29(1), 86-95.

Haugh, D., Ollivaud, P. \& Turner, D. (2009). The Macroeconomic Consequences of Banking Crises in OECD Countries. OECD Economics Department Working Papers No. 683. Paris: Organisation for Economic Co-operation and Development.

Hutchison, M. M., \& Noy, I. (2005). How Bad Are Twins? Output Costs of Currency and Banking Crises. Journal of Money, Credit and Banking, $37(4), 725-752$.

International Monetary Fund (2009). Global Financial Stability Report. Washington D.C.: International Monetary Fund, April.

International Monetary Fund (2014). Global Financial Stability Report. Washington D.C.: International Monetary Fund, April.

Isard, P. (2005). Globalization and the International Financial System: What's Wrong and What Can Be Done. Cambridge, United Kingdom: Cambridge 
University Press.

Kalemli-Ozcan, S., Sorensen, B., \& Yesiltas, S. (2012). Leverage Across Firms, Banks, and Countries. Journal of International Economics, 88(2), $284-298$.

Kaminsky, G. L., \& Reinhart, C. M. (1999). The Twin Crises: The Causes of Banking and Balance-of-Payments Problems. American Economic Review, 89(3), 473-500.

Kaminsky, G. L., \& Reinhart, C. M. (2008). The Center and the Periphery: The Globalization of Financial Turmoil. In C. M. Reinhart, C. A. Vegh, \& A. Velasco (Eds.), Money, Crises, and Transition: Essays in Honor of Guillermo Calvo. Cambridge, Massachusetts: The MIT Press.

Kedem, B. (1980). Binary Time Series. Volume 52 of Lecture Notes in Pure and Applied Mathematics. New York and Basel: Marcel Dekker.

Kindleberger, C. P., \& Aliber, R. Z. (2011). Manias, Panics and Crashes: A History of Financial Crises. New York: Palgrave Macmillan.

Kodres, L. E. \& Pritsker, M. (2002). A Rational Expectations Model of Financial Contagion. The Journal of Finance, 57(2), 769-799.

Laeven, L., \& Valencia, F. (2008). Systemic Banking Crises: A New Database. IMF Working Papers No. 08/224. Washington, D.C.: International Monetary Fund.

Laeven, L., \& Valencia, F. (2010). Resolution of Banking Crises: The Good, the Bad, and the Ugly. IMF Working Papers No. 10/146. Washington, D.C.: International Monetary Fund. 
Laeven, L., \& Valencia, F. (2013). Systemic Banking Crises Database. IMF Economic Review, 61(2), 225-270.

Lane P. R. \& Milesi-Ferretti, G. M. (2012). External adjustment and the global crisis, Journal of International Economics, 88(2), 252-265.

Lestano, \& Jacobs, J. P. A. M. (2007). Dating Currency Crises with Ad Hoc and Extreme Value Based Thresholds: East Asia 1970-2002. International Journal of Finance and Economics, 12(4), 371-388.

Organisation for Economic Co-operation and Development (2010). Roundtable on Competition, Concentration and Stability in the Banking Sector. DAF/COMP(2010)9. Paris: Organisation for Economic Co-operation and Development

Ostry, J. D., Ghosh, A. R., Habermeier, E., Chamon, M., Qureshi, M. S., \& Reinhardt, D. B. S. (2010). Capital Inflows: The Role of Controls. IMF Staff Position Note No. SPN/1-/04. Washington, D.C.: International Monetary Fund.

Raddatz, C., \& Schmukler, S. L. (2012). On the International Transmission of Shocks: Micro-Evidence from Mutual Fund Portfolios. Journal of International Economics, 88(2), 357-374.

Reinhart, C. M., \& Rogoff, K. S. (2011). This Time is Different: Eight Centuries of Financial Folly. Princeton and Oxford: Princeton University Press.

Rose, A. K., \& Spiegel, M. M. (2010). Cross-Country Causes and Consequences of the 2008 Crisis: International Linkages and American Exposure. Pacific Economic Review, 15(13), 340-363. 
Schinasi, G. J., \& Truman, E. M. (2010). Reform of the Global Financial Architecture. Working Paper Series No. 10-14. Washington, D.C.: Peterson Institute for International Economics.

Shehzad, C.T., \& De Haan, J. (2013). Was the 2007 Crisis Really a Global Banking Crisis. North American Journal of Economics and Finance, 24, $113-124$.

Shin, H. S. (2009). Reflections on Northern Rock: The Bank Run That Heralded the Global Financial Crisis. Journal of Economic Perspectives, 23(1), 101-119.

Stiglitz, J. E. (2000). Must Financial Crises be this Frequent and this Painful? In P.-R. Agénor, M. Miller, D. Vines, \& A. Weber (Eds.), The Asian Financial Crisis: Causes, Contagion and Consequences. Cambridge, United Kingdom: Cambridge University Press.

Sylla, R. \& Wright, R.E. (2004). Networks and Historys Generalizations: Comparing the Financial Systems of Germany, Japan, Great Britain, and the United States of America. Business and Economic History On-Line, $2,1-25$.

Van Rijckeghem, C. \& Weder, B. (2001). Sources of Contagion: Is it Finance or Trade? Journal of International Economics, 54(2), 293-308.

Van Rijckeghem, C. \& Weder, B. (2003). Spillovers through Banking Centers: A Panel Data Analysis of Bank Flows. Journal of International Money and Finance, 22(4), 438-509. 
Table 1:

Occurrences of Financial Crises: 1883-2008

\begin{tabular}{lccc} 
& Currency Crises & Banking Crises & Twin Crises \\
\hline Argentina & 20 & 9 & 4 \\
Australia & 7 & 2 & 0 \\
Belgium & 5 & 6 & 0 \\
Brazil & 14 & 9 & 3 \\
Canada & 10 & 1 & 0 \\
Chile & 10 & 5 & 1 \\
Denmark & 8 & 6 & 2 \\
Finland & 7 & 5 & 3 \\
France & 9 & 7 & 0 \\
Germany & 5 & 4 & 1 \\
Greece & 7 & 2 & 1 \\
Italy & 8 & 9 & 1 \\
Japan & 7 & 4 & 0 \\
Netherlands & 6 & 4 & 1 \\
Norway & 4 & 5 & 1 \\
Portugal & 6 & 6 & 2 \\
Spain & 8 & 5 & 1 \\
Sweden & 5 & 5 & 2 \\
Switzerland & 4 & 3 & 0 \\
UK & 11 & 3 & 0 \\
US & 7 & 11 & 2 \\
All countries & 168 & 111 & 25 \\
\hline
\end{tabular}


Table 2: Univariate Tests of Independence versus First Order Markov Process: $p$-values

\begin{tabular}{lcc} 
& Currency Crises & Banking Crises \\
\hline Argentina & 0.2611 & 0.3793 \\
Australia & 0.2893 & 0.9681 \\
Belgium & 0.8126 & 0.1751 \\
Brazil & 0.1406 & 0.1098 \\
Canada & 0.4203 & 0.9920 \\
Chile & 0.4203 & 0.8126 \\
Denmark & $\mathbf{0 . 0 0 8 0}$ & 0.2336 \\
Finland & 0.6612 & 0.8126 \\
France & 0.3739 & $\mathbf{0 . 0 2 5 4}$ \\
Germany & 0.8126 & 0.9292 \\
Greece & 0.2893 & 0.9920 \\
Italy & 0.3373 & 0.3373 \\
Japan & 0.2893 & 0.8766 \\
Netherlands & 0.7398 & 0.9292 \\
Norway & 0.8766 & $\mathbf{0 . 0 1 2 0}$ \\
Portugal & 0.7398 & 0.1751 \\
Spain & 0.5798 & 0.1751 \\
Sweden & 0.1751 & 0.1751 \\
Switzerland & 0.8766 & 0.9681 \\
UK & $\mathbf{0 . 0 4 9 0}$ & 0.9681 \\
US & 0.2893 & $\mathbf{0 . 0 0 3 3}$ \\
\hline
\end{tabular}




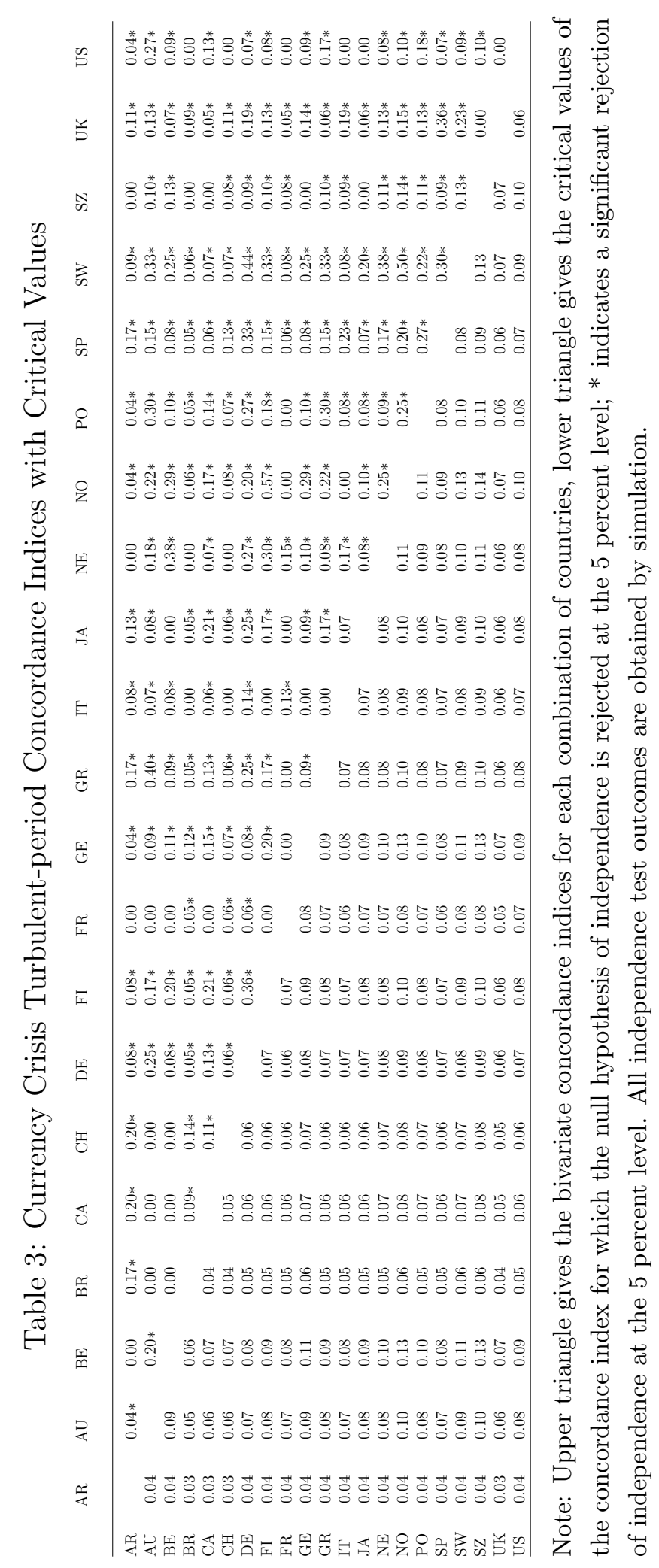




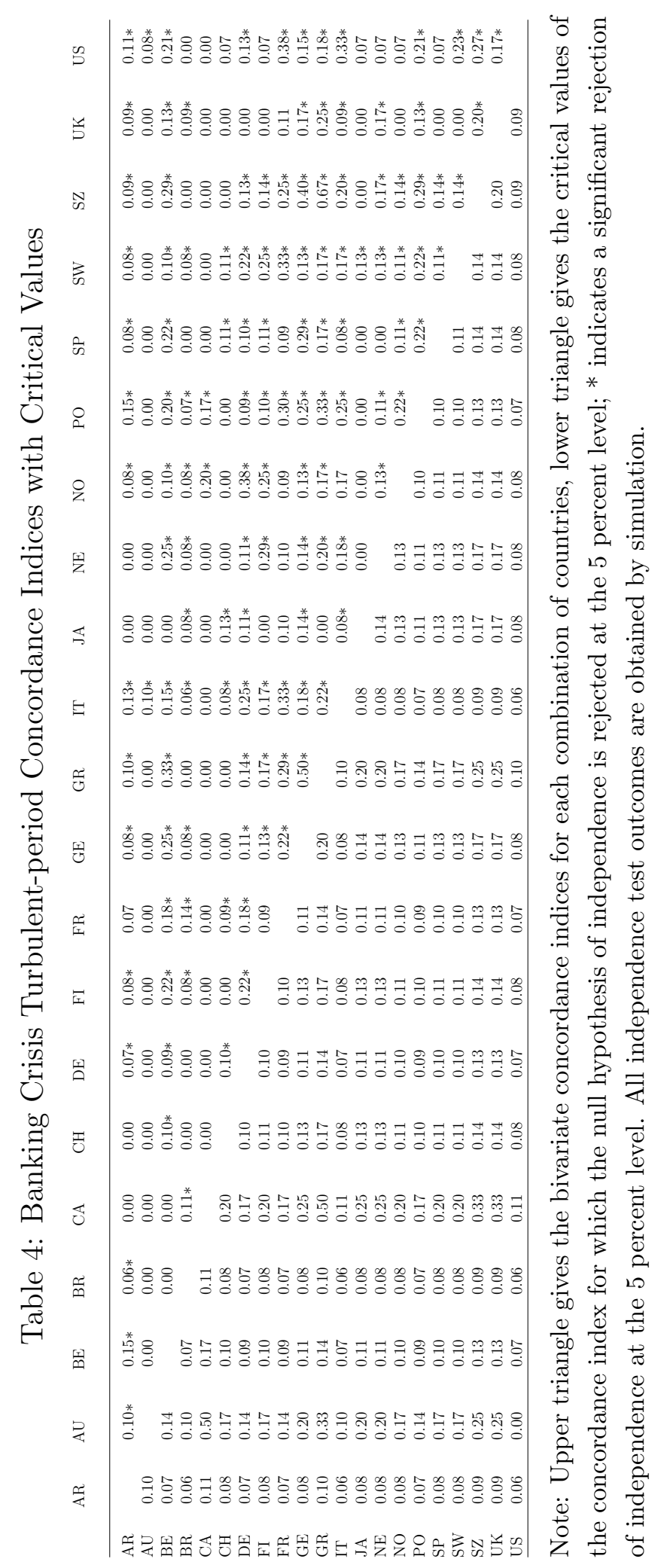


Table 5:

Multivariate Concordance Indices

\begin{tabular}{lccc} 
& Index value & Observations & Critical Values \\
\hline Currency crises & across countries & & \\
At least 2 crises & 0.57 & 39 & 18 \\
At least 3 crises & 0.29 & 20 & 7 \\
At least 4 crises & 0.14 & 10 & 3 \\
At least 5 crises & 0.10 & 7 & 1 \\
At least 6 crises & 0.09 & 6 & 1 \\
At least 7 crises & 0.06 & 4 & 1 \\
At least 8 crises & 0.04 & 3 & 1 \\
At least 10 crises & 0.03 & 2 & 1 \\
At least 12 crises & 0.03 & 2 & 1 \\
At least 14 crises & 0.01 & 1 & 1 \\
Crises observations $\left(n-n_{z=0}\right)$ & 69 & \\
\hline
\end{tabular}

Banking crises across countries

$\begin{array}{llll}\text { At least } 2 \text { crises } & 0.59 & 26 & 7 \\ \text { At least } 3 \text { crises } & 0.34 & 5 & 2 \\ \text { At least } 4 \text { crises } & 0.14 & 6 & 1 \\ \text { At least } 5 \text { crises } & 0.09 & 7 & 1 \\ \text { At least } 6 \text { crises } & 0.07 & 3 & 1 \\ \text { At least } 7 \text { crises } & 0.07 & 3 & 1 \\ \text { At least } 8 \text { crises } & 0.05 & 2 & 1 \\ \text { At least } 10 \text { crises } & 0.05 & 2 & 1 \\ \text { At least } 12 \text { crises } & 0.02 & 1 & 1 \\ \text { At least } 13 \text { crises } & 0.02 & 1 & 1\end{array}$

Crises observations $\left(n-n_{z=0}\right) \quad 44$

Note: the critical value gives the maximum number of observations for the case at hand that rejects the null hypothesis of multivariate independence at the 5 per cent level. 
Table 6:

Simultaneity of Currency and Banking Crises

\begin{tabular}{|c|c|c|c|c|c|}
\hline & \multicolumn{4}{|c|}{$\begin{array}{l}\text { Number of periods } \\
\text { with } z \text { simultaneous } \\
\text { banking crises }\end{array}$} & \multirow[t]{2}{*}{ Total } \\
\hline & & $z=$ & $z=$ & $z \geq 2$ & \\
\hline Number of periods & $z=0$ & 46 & 4 & 7 & 57 \\
\hline with $z$ simultaneous & $z=1$ & 19 & 5 & 6 & 30 \\
\hline currency crises & $z \geq 2$ & 17 & 9 & 13 & 39 \\
\hline Total & & 82 & 18 & 26 & 126 \\
\hline
\end{tabular}


Figure 1: Turbulent-periods Concordance Index for Two Series with Equal Means and All Feasible Correlations

Insert MardiJanLestano-Figure1.pdf here. 
Figure 2: Multivariate Turbulent Periods Concordance Index for Two or More Simultaneous Crises as a Function of the Number of Single Crisis Periods $n_{z=1}$ and the Number of Tranquil Periods $n_{z=0}$

Insert MardiJanLestano-Figure2.pdf here. 
Figure 3: Distribution of Currency Crises over 1883-2008

Insert MardiJanLestano-Figure3.pdf here. 
Figure 4: Distribution of Banking Crises over 1883-2008

Insert MardiJanLestano-Figure4.pdf here. 
Figure 5: Recursive Multivariate Concordance Indices, 1902-2008

Insert MardiJanLestano-Figure5.pdf here. 